\title{
Efek Antihipertensi Ekstrak Etanol Kombinasi Rambut dan Biji Jagung (Zea mays L.) pada Tikus Hipertensi yang Diinduksi Monosodium Glutamat
}

\author{
Yance Anas $^{1^{*)}}$ dan Naimi Amalia Hatimah ${ }^{2)}$ \\ ${ }^{1)}$ Bagian Farmakologi dan Farmasi Klinik Fakultas Farmasi Universitas Wahid Hasyim Semarang \\ ${ }^{2)}$ Program Studi S1-Farmasi Fakultas Farmasi Universitas Wahid Hasyim Semarang \\ Jl. Menoreh Tengah X/22 Sampangan Semarang 50236 \\ e-mail: yance.apt@gmail.com
}

\section{INTISARI}

Penelitian sebelumnya membuktikan bahwa infus rambut dan jus biji jagung memiliki efek antihipertensi pada tikus jantan sehingga dapat dikembangkan dalam bentuk ekstrak. Penelitian ini bertujuan untuk membuktikan efek antihipertensi ekstrak etanol kombinasi rambut dan biji jagung (EEK-RBJ) pada tikus hipertensi yang diinduksi monosodium glutamat (MSG). EEK-RBJ dibuat menggunakan metode maserasi. Tikus hipertensi dibuat dengan cara pemberian MSG 100 $\mathrm{mg} / \mathrm{kgBB} /$ hari selama 14 hari sampai tekanan darah sistol $\geq 155 \mathrm{mmHg}$. Tikus hipertensi yang digunakan sebanyak 25 ekor, dibagi menjadi 5 kelompok yaitu kelompok kontrol hipertensi (CMC$\mathrm{Na}$ 0,5\% 12,5 mL/kgBB/hari), kelompok furosemid 5,04 mg/kgBB/hari), dan kelompok EEK-RBJ $(125,250$ dan 500) $\mathrm{mg} / \mathrm{kgBB} /$ hari. Sediaan uji diberikan satu kali sehari selama 14 hari (p.o). Data yang diamati adalah perbedaan tekanan darah sistol dan diastol sebelum dan setelah pemberian sediaan uji serta perbedaan penurunan tekanan darah. Data perbedaan tekana darah dianalisa secara statistik menggunakan uji t-berpasangan atau uji Wilcoxon (P: 0,95). Hasil penelitian menyimpulkan bahwa EEK-RBJ $(125,250$ dan 500) $\mathrm{mg} / \mathrm{Kg} \mathrm{BB} /$ hari selama 14 hari mampu menurunkan tekanan darah sistol dan diastol tikus hipertensi dengan pola tergantung dosis. EEKRBJ $500 \mathrm{mg} / \mathrm{Kg} \mathrm{BB} /$ hari dapat menurunkan tekanan darah sistol dan diastol tikus hipertensi yang diinduksi MSG berturut-turut sebesar 20,04 $\mathrm{mmHg}$ dan 13,16 mmHg.

Kata Kunci: Efek antihipertensi, ekstrak kombinasi, rambut dan biji jagung, MSG

\section{ABSTRACT}

In previous studies, infusion of silk and corn seed combination have antihypertensive effects, so it can develop in the form of extracts. The purpose of this study is to reveal the antihypertensive effect of a silk and seed corn ethanol extract (SSC-EE) on MSG-induced hypertensive rats. SSC-EE produced with maceration. MSG $100 \mathrm{mg} / \mathrm{kg} \mathrm{BW/day} \mathrm{for} 14$ days orally used to induce hypertension condition in male Wistar rats until systolic blood pressure $\geq 150$ $\mathrm{mmHg}$. Twenty-five of hypertensive rats divided into five groups. Hypertensive rats in Group I treated with CMC-Na $0.5 \% 12.5 \mathrm{~mL} / \mathrm{kg}$ BW/day and group II treated with Furosemide $5.04 \mathrm{mg} / \mathrm{kg}$ BW/day. Meanwhile, group III, IV and V treated with SSC-EE (125, 250 and 500) mg/kg BW/day. SSC-EE was treated orally once daily for 14 days. Systolic and diastolic blood pressure, before and after of extracts treatment and blood pressure decline was observed and analyzed statistically using paired t-test or Wilcoxon test (P: 0.95). The results show that SSC-EE $(125,250$ and 500) $\mathrm{mg} / \mathrm{Kg}$ $\mathrm{BW} /$ day for 14 days can decrease the MSG-induced hypertensive rats systolic and diastolic blood pressure $(\mathrm{p}<0.05)$ with the dose-dependent manner. SSC-EE $500 \mathrm{mg} / \mathrm{Kg} \mathrm{BW} /$ day decrease the systolic and diastolic blood pressure of $20.04 \mathrm{mmHg}$ and $13.16 \mathrm{mmHg}$, respectively.

Keywords: Antihypertensive effect, combination extract, silk and seed corn, MSG 
Corresponding author:

Yance Anas

Bagian Farmakologi dan Farmasi Klinik Fakultas Farmasi Universitas Wahid Hasyim Semarang

Jl. Menoreh Tengah X/22 Sampangan-Semarang 50236

E-mail: yance.apt@gmail.com

\section{PENDAHULUAN}

Jagung telah lama dikenal sebagai salah satu bahan pokok atau makanan di Indonesia. Saat ini, rambut dan biji jagung telah dimanfaatkan dalam penelitian untuk penemuan senyawa obat. Secara khusus, penelusuran senyawa aktif dalam rambut dan biji jagung dilakukan untuk penemuan antihipertensi baru. Hasil penelitian Kadir (2009) telah membuktikan khasiat diuretik dari jus dan rebusan tongkol jagung muda pada kelinci. Infusa kombinasi rambut dan biji jagung (50:50) telah terbukti mampu menurunkan tekanan darah sistol dan diastol pada tikus jantan (Herman dan Bayu, 2015), sehingga berpotensi dikembangkan lebih lanjut sebagai antihipertensi dalam bentuk ekstrak. Selain itu, ekstrak air rambut jagung $260 \mathrm{mg} / \mathrm{Kg}$ BB juga telah terbukti mampu menurunkan tekanan darah 20 orang penderita hipertensi. Kandungan kalium yang tinggi pada ekstrak air rambut jagung diduga kuat bertanggung jawab terhadap efek diuretik dan penurunan tekanan darah penderita hipertensi tersebut (George dan Idu, 2015). Obat yang berkhasiat sebagai diuretik telah lama digunakan secara luas dalam pengobatan berbagai penyakit, seperti dalam pengobatan sistitis, batu ginjal, nefritis, hipertensi dan gangguan kelanjar prostat (Bhaigyabati, dkk., 2011).

Sediaan uji yang digunakan dalam penelitian ini adalah ekstrak etanol kombinasi rambut dan biji jagung (EEK-RBJ). Perbandingan jumlah simplisia kering rambut jagung dan biji jagung dalam pembuatan ekstrak kombinasi adalah 1:1. Efek antihipertensi EEK-RBJ diujikan pada model tikus hipertensi yang diinduksi monosodium glutamat (MSG). Perlakuan MSG 100 mg/Kg BB/hari selama 14 hari telah terbukti mampu meningkatkan tekanan darah sistol dan diastol tikus jantan galur Wistar dengan profil tekanan darah sistol > $155 \mathrm{mmHg}$. Peningkatan tekanan darah tikus tersebut mampu bertahan lebih dari 14 hari (Hidayati, dkk., 2015) sehingga dapat digunakan untuk mengevaluasi efek antihipertensi kandidat obat atau bahan alam. EEK-RBJ dinyatakan memiliki efek antihipertensi apabila mampu menurunkan tekanan darah sistol dan diastol tikus hipertensi yang diinduksi MSG secara signifikan $(\mathrm{p}<0,05)$. Tujuan lain dari penelitian ini adalah mengevaluasi pola efek antihipertensi EEK-RBJ berdasarkan dosis yang digunakan dalam penelitian ini.

\section{METODE PENELITIAN}

\section{A. Rancangan Penelitian}

Penelitian ini merupakan penelitian eksperimental dengan rancangan randomize matched pretest and post-test control group.

\section{B. Variabel Penelitian}

1. Variabel bebas Peringkat dosis EEK-RBJ

2. Variabel tergantung Penurunan tekanan darah sistol, diastol, dan pola efek antihipertensi

3. Variabel terkendali

Galur, jenis kelamin, usia, berat badan, tingkat kestressan tikus, kondisi lingkungan (cahaya, suhu, suara), pakan dan minuman. 


\section{Pengambilan Sampel}

Jagung yang digunakan adalah jagung yang telah matang, dipanen dari kebun jagung di kecamatan Sumowono, Kabupaten Semarang, Jawa Tengah. Proses identifikasi sampel rambut dan biji jagung dilakukan oleh ahli botani di Laboratorium Ekologi dan Biosistematika, Jurusan Biologi, Fakultas Matematika dan Ilmu Pengetahuan Alam, Universitas Diponegoro Semarang menggunakan pustaka acuan Flora of Java karangan Backer dan Bakhulzen (1965). Sampel rambut dan biji jagung tersebut disimpan pada laboratorium tersebut dan Surat Keterangan Hasil Identifikasi disimpan di Laboratorium Farmakologi Universitas Wahid Hasyim.

\section{Alat dan Bahan}

1. Bahan

Bahan utama yang digunakan dalam penelitian ini adalah rambut dan biji jagung. Berbagai bahan lain yang digunakan antara lain etanol 70\% (PT. Brataco Chemika), monosodium glumatat (PT. Ajinomoto), CMC-Na (PT. Brataco Chemika), furosemid (PT. Shamparindo Semarang).

2. Hewan Percobaan

Tikus jantan galur Wistar usia 2-3 bulan dengan berat badan $\pm 200-300$ gram. Tikus diperoleh dari peternakan hewan percobaan dari daerah Bandungan, Kecamatan Sumowono, Kabupaten Semarang, Jawa Tengah. Tikus ini dipelihara dalam kondisi laboratorium di Laboratorium Farmakologi Universitas Wahid Hasyim Semarang.

3. Alat

Alat yang digunakan dalam penelitian adalah timbangan elektrik (Henherr), oven (Memmert), blender (Philiph), ayakan Mesh 40, moisture balance (Ohaus), seperangkat toples maserasi, rotary evaporator (Heidolp), timbangan hewan uji (Daema) dan blood pressure analyzer merk CODA (Kent Scientific)

\section{E. Pembuatan Ekstrak Etanol Kombinasi Rambut dan Biji Jagung (EEK-RBJ)}

Rambut dan biji jagung yang telah dipanen, disortasi basah, dan selanjutnya dicuci bersih dengan air mengalir, kemudian dikeringkan dalam oven. Rambut jagung dikeringkan pada suhu $30-45^{\circ} \mathrm{C}$ (Garnida., 2018), sedangkan biji jagung dikeringkan dengan suhu $50^{\circ} \mathrm{C}$ (Djaeni, dkk., 2014). Simplisia yang sudah dikeringkan dihaluskan menggunakan blender dan diukur kadar airnya dengan moisture balance. Rambut dan biji jagung diekstraksi dengan metode maserasi dengan menggunakan etanol 70\%. Jumlah simplisia kering rambut jagung dan biji jagung yang digunakan dalam proses ekstraksi adalah masing-masing seberat $250 \mathrm{~g}$. Proses maserasi dilakukan dilakukan secara bertahap (tahap 1 selama 3 hari dan tahap 2 selama 2 hari). EEK-RBJ dipekatkan dengan rotary evaporator pada suhu $60^{\circ} \mathrm{C}$ (Handa, dkk., 2008), dikumpulkan dan ditimbang bobotnya untuk perhitungan rendemen menggunakan rumus berikut:

\section{Rendemen EEKRBJ $(\%)=\frac{\text { Bobot Ekstrak }}{\text { Bobot Simplisĩa Rambut dan Bijīi Jagung }} \times 100 \%$}

\section{F. Pembuatan Tikus Hipertensi}

Sebelum digunakan dalam penelitian, semua tikus jantan galur Wistar diadaptasikan terlebih dahulu dalam kondisi laboratorium penelitian dan di dalam holder selama 7 hari untuk mengurangi tingkat kestressan tikus. Tikus dikeluar-masukkan ke dalam holder selama 10 menit setiap harinya. Sebanyak 25 ekor tikus diberi perlakuan MSG $100 \mathrm{mg} / \mathrm{kgBB}$ (p.o) satu kali sehari selama 14 hari untuk memicu terjadinya peningkatan tekanan darah (hipertensi). Tekanan darah sistol dan diastol tikus setelah perlakuan diukur dengan menggunakan blood pressure analyzer merk CODA (Kent 
Scientific). Tikus dikatakan hipertensi apabila hasil pengukuran tekanan darah sistol pada hari ke15 setelah perlakuan MSG $\geq 155 \mathrm{mmHg}$ (Hidayati, dkk., 2015).

\section{G. Uji Aktivitas Antihipertensi EEKRBJ pada Tikus Hipertensi yang diinduksi MSG}

Sebanyak 25 ekor tikus hipertensi dikelompokkan secara acak pada 5 kelompok perlakuan (masing-masing terdiri dari 5 ekor tikus), yaitu kelompok kontrol hipertensi (perlakuan CMC-Na 0,5\% 12,5 $\mathrm{mL} / \mathrm{kgBB} / \mathrm{hari}$ ), kelompok Furosemid (perlakuan furosemid 5,04 $\mathrm{mg} / \mathrm{kgBB} / \mathrm{hari}$ ) dan kelompok EEK-RBJ (perlakuan EEK-RBJ $(125,250$ dan 500) $\mathrm{mg} / \mathrm{kgBB} / \mathrm{hari})$. Data tekanan darah sistol dan diastol semua tikus hipertensi diukur terlebih dahulu sebelum pemberian sediaan uji. Selanjutnya, sedian uji diberikan secara oral pada tikus hipertensi satu kali sehari selama 14 hari. Pada hari ke-15 setelah pemberian sediaan uji, data tekanan darah sistol dan diastol tikus hipertensi diukur kembali dan digunakan untuk perhitungan data penurunan tekanan darah sistol dan diastole (Hidayati, dkk., 2015). Efek antihipertensi ditandai dengan terjadinya penurunan tekanan darah sistol dan diastol secara statistik pada taraf kepercayaan 95\% (P: 0,95).

\section{H. Data dan Analisis Data}

Data tekanan darah sistol/diastol sebelum dan setelah perlakuan sediaan uji dinyatakan dalam bentuk rata-rata $(\mathrm{mmHg} \pm \mathrm{SEM} ; \mathrm{n}=5)$. Data penurunan tekanan darah didapatkan dari selisih tekanan darah sistol/diastol sebelum dan setelah perlakuan. Pola distribusi data diuji diuji dengan uji normalitas menggunakan metode Kolsmogoroff-Smirnoff dan Saphiro-Wilk (P: 0,95). Tingkat homogenitas varian data penurunan tekanan darah $(\mathrm{mmHg} \pm \mathrm{SEM} ; \mathrm{n}=5)$ diuji dengan metode Levene Test (p: 0,95). Perbedaan tekanan darah sistol/diastol diuji diuji dengan uji T-berpasangan atau uji Wilcoxon (P: 0,95). Sementara itu, perbedaan penurunan tekanan darah tikus kelompok peringkat dosis EEK-RBJ diuji dengan Anova satu jalan yang dilanjutkan dengan uji Tukey (P: 0,95). Nilai signifikansi (p) kurang dari 0,05 menunjukkan adanya perbedaan yang signifikan.

\section{HASIL DAN PEMBAHASAN}

\section{A. Simplisia dan Ekstrak Etanol Kombinasi Rambut dan Biji Jagung (EEK-RBJ)}

Rambut dan biji jagung dapat dikeringkan dalam oven pada suhu rendah. Kandungan air simplisia rambut dan biji jagung dalam penelitian ini adalah 3,8\% dan telah memenuhi persyaratan simplisia yang baik (Depkes RI, 1985). Susut pengeringan rambut jagung adalah sebesar 49,0 \% . Sementara itu, susut pengeringan biji jagung adalah sebesar 37,5\%. EEK-RBJ dalam penelitian ini dibuat dengan menggunakan metode maserasi. Masing-masing sebanyak $250 \mathrm{~g}$ simplisia rambut dan biji jagung dicampur jadi satu dan direndam dalam etanol 70\%. EEK-RBJ (gambar 1) yang dihasilkan adalah sebanyak $45 \mathrm{~g}$ (rendemen 9,0 \%). Sifat organoleptis dari EEK-RBJ adalah ekstrak berwarna coklat, kental dan berbau khas jagung.

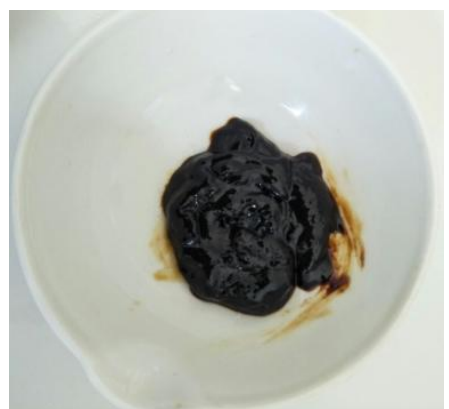

Gambar 1. Ekstrak etanol kombinasi rambut dan biji jagung

JIFFK Vol. 15, No. 1, JUNI 2018, Hal. 29 - 36 


\section{B. Efek Antihipertensi EEK-RBJ pada Tekanan Darah Sistol Tikus Hipertensi yang Diinduksi MSG}

Tekanan darah sistol tikus hipertensi akibat perlakuan MSG $100 \mathrm{mg} / \mathrm{Kg}$ BB selama 14 hari adalah $(161,76 \pm 0,061) \mathrm{mmHg}$. Tekanan darah ini menggambarkan tekanan darah sistol tikus hipertensi. Perlakuan Furosemid 5,04 mg/Kg BB/hari dan EEK-RBJ (125, 250 dan 500) mg/Kg $\mathrm{BB} /$ hari selama 14 hari terbukti mampu menurunkan tekanan darah sistol secara signifikan $(\mathrm{p}<0,05)$. Sementara itu, perlakuan CMC-Na $0,5 \% 12,5 \mathrm{~mL} / \mathrm{Kg} \mathrm{BB} / \mathrm{hari}$ tidak berpengaruh pada tekanan darah sistol tikus hipertensi yang diinduksi MSG (Gambar 2).

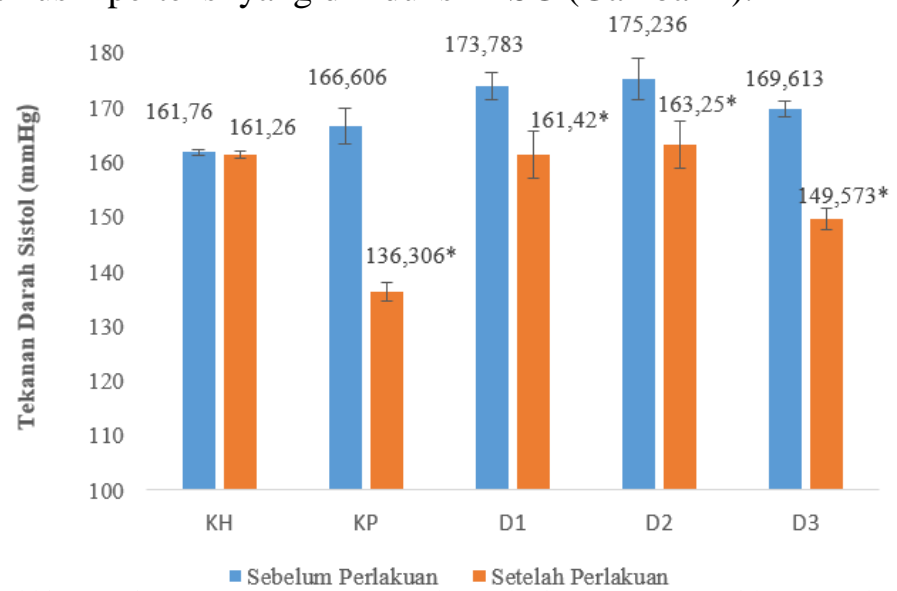

Keterangan : $\quad \mathrm{KH}=$ Kontrol hipertensi $(\mathrm{CMC}-\mathrm{Na}$ 0,5\% 12,5 mL/kgBB/hari); KP = Furosemid 5,04 mg/kgBB/hari; D1 = EEK-RBJ $125 \mathrm{mg} / \mathrm{kgBB} / \mathrm{hari}$; D2 = EEK-RBJ $250 \mathrm{mg} / \mathrm{kgBB} / \mathrm{hari}$; D3 = EEKRBJ $500 \mathrm{mg} / \mathrm{kgBB} / \mathrm{hari}$

Gambar 2. Perbandingan rata-rata tekanan darah sistol $(\mathbf{m m H g} \pm \mathrm{SEM})$ sebelum dan setelah pemberian sediaan uji selama 14 hari $(\mathbf{n}=5)$.* Hasil uji T-berpasangan menunjukkan adanya perbedaan yang signifikan dengan tekanan darah sistol sebelum perlakuan $(\mathrm{p}<0,05)$.

\section{Efek Antihipertensi EEK-RBJ pada Tekanan Darah Diastol Tikus Hipertensi yang Diinduksi MSG}

Penelitian ini juga mengukur efek antihipertensi EEK-RBJ pada tekanan darah sistol tikus hipertensi. Tekanan darah diastol tikus hipertensi akibat perlakuan MSG $100 \mathrm{mg} / \mathrm{Kg}$ BB selama 14 hari adalah $(128,66 \pm 0,60) \mathrm{mmHg}$. Perlakuan Furosemid 5,04 mg/Kg BB/hari dan EEK-RBJ (125, 250 dan 500) $\mathrm{mg} / \mathrm{Kg} \mathrm{BB} /$ hari selama 14 hari juga mampu menurunkan tekanan darah diastol tikus hipertensi secara signifikan $(\mathrm{p}<0,05)$. Sementara itu, perlakuan CMC-Na 0,5\% 12,5 $\mathrm{mL} / \mathrm{Kg}$ $\mathrm{BB} /$ hari juga tidak berpengaruh pada tekanan darah diastol tikus hipertensi (Gambar 3).

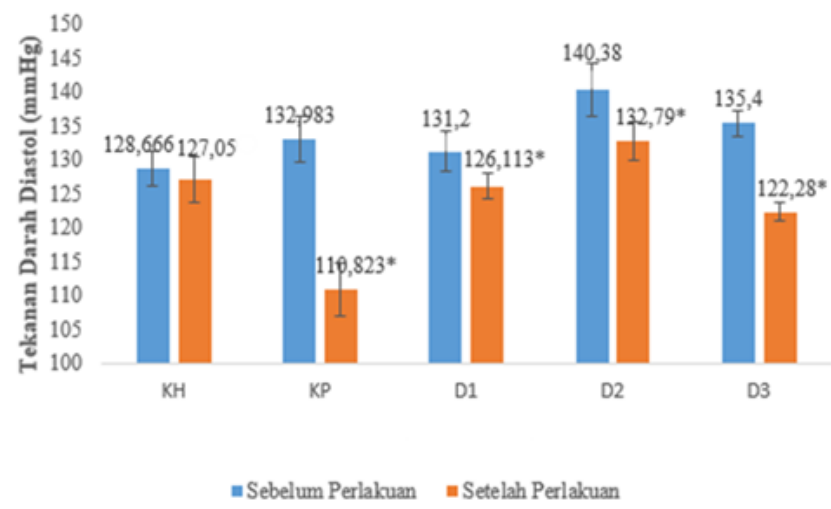

Keterangan : $\quad \mathrm{KH}=$ Kontrol hipertensi $(\mathrm{CMC}-\mathrm{Na}$ 0,5\% 12,5 mL/kgBB/hari); KP = Furosemid 5,04 mg/kgBB/hari; D1 = EEK-RBJ $125 \mathrm{mg} / \mathrm{kgBB} / \mathrm{hari} ; \mathrm{D} 2$ = EEK-RBJ $250 \mathrm{mg} / \mathrm{kgBB} / \mathrm{hari}$; D3 = EEKRBJ $500 \mathrm{mg} / \mathrm{kgBB} / \mathrm{hari}$ 
Gambar 3. Perbandingan rata-rata tekanan darah diastole (mmHg \pm SEM) sebelum dan setelah pemberian sediaan uji selama 14 hari $(\mathbf{n = 5})$.* Hasil uji T-berpasangan atau uji Wilcoxon menunjukkan adanya perbedaan yang signifikan dengan tekanan darah sistol sebelum perlakuan $(\mathrm{p}<0,05)$.

\section{Pola Efek Antihipertensi EEK-RBJ}

Data yang diukur pada penentuan pola efek antihipertensi EEK-RBJ adalah data penurunan tekanan darah sistol dan diastol tikus hipertensi yang diinduksi MSG setelah mendapatkan perlakuan tiga peringkat dosis EEK-RBJ (Gambar 4). Hasil penelitian ini menyimpulkan bahwa efek antihipertensi EEK-RBJ mengikuti pola tergantung dosis. Berdasarkan penurunan tekanan darah sistol dan diastol tikus hipertensi, peningkatan efek antihipertensi baru terjadi pada peningkatan dosis dari $125 \mathrm{mg} / \mathrm{kg} \mathrm{BB} /$ hari ke $500 \mathrm{mg} / \mathrm{kgBB} / \mathrm{hari}(\mathrm{p}<0,05)$. Sementara itu, EEKRBJ (125 dan 250) mg/kg BB/hari memiliki kemampuan yang setara dalam menurunkan tekanan darah sistol dan diastol tikus hipertensi yang diinduksi MSG. EEK-RBJ $500 \mathrm{mg} / \mathrm{Kg}$ BB/hari selama 14 hari mampu menurunkan tekanan darah tikus hipertensi yang diinduksi MSG sebesar 20,04 $\mathrm{mmHg}$ (sistol) dan 13,16 mmHg (diastol).

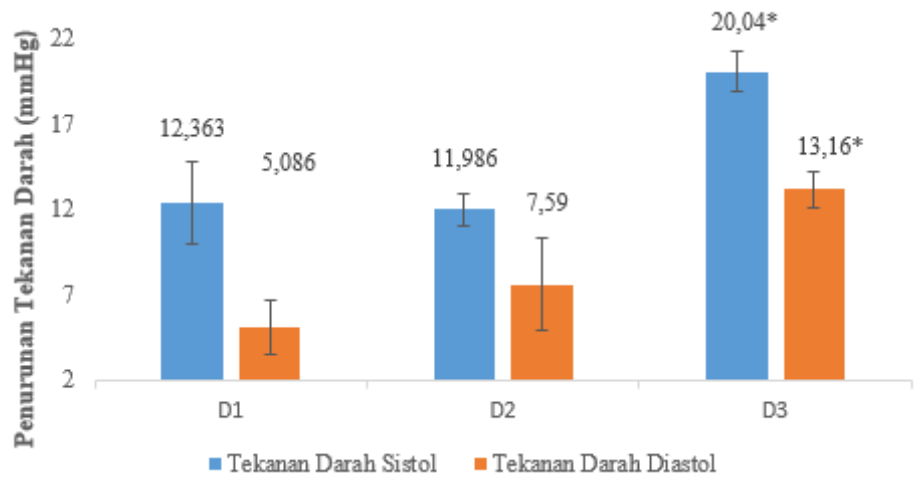

Keterangan : $\quad$ D1= EEK-RBJ $125 \mathrm{mg} / \mathrm{kgBB} / \mathrm{hari} ; \mathrm{D} 2$ = EEK-RBJ $250 \mathrm{mg} / \mathrm{kgBB} / \mathrm{hari} ; \mathrm{D} 3=$ EEKRBJ $500 \mathrm{mg} / \mathrm{kgBB} / \mathrm{hari}$

Gambar 4. Rata-rata penurunan tekanan darah sistol dan diastol tikus hipertensi (mmHg \pm SEM) setelah mendapat perlakuan tiga peringkat dosis EEK-RBJ *Uji Tukey menunjukkan adanya perbedaan bermakna dengan dosis $125 \mathrm{mg} / \mathrm{kgBB} / \mathrm{hari}(\mathrm{p}<0,05)$

Penelitian ini menyimpulkan bahwa ketiga peringkat dosis EEK-RBJ terbukti mampu menurunkan tekanan darah sistol dan diastol tikus hipertensi dengan pola tergantung dosis. Pada berbagai penelitian sebelumnya, beberapa kandungan senyawa aktif telah berhasil ditemukan dalam ekstrak etanol rambut jagung, diantaranya adalah senyawa saponin, minyak atsiri, alkaloid (Yuniarti, 2008), tanin, (Guo, dkk., 2009), flavonoid dan alkaloid (Yosmar, dkk., 2014). Sementara itu, kandungan senyawa aktif yang ditemukan pada biji jagung yaitu karotenoid, flavonoid dan polifenol (Žilić, dkk., 2012).

Berbagai efek antihipertensi senyawa aktif tersebut telah banyak dibuktikan oleh peneliti terdahulu. Senyawa alkaloid memiliki efek diuretik sehingga mampu menurunkan tekanan darah. Alkaloid bekerja langsung pada tubulus ginjal dengan cara meningkatkan ekskresi $\mathrm{Na}^{+}$dan $\mathrm{Cl}^{-}$ (Nessa, dkk., 2013). Sementara itu, senyawa tannin dapat menurunkan tekanan darah melalui kemampuannya dalam menghambat vasokontriksi pembuluh darah (Diennazola, 2012). Kuersetin, salah satu senyawa golongan flavonoid juga telah terbukti dapat menurunkan tekanan darah sistol pada tikus (Larson, dkk., 2010). Kuersetin dosis tinggi dilaporkan mampu menurunkan tekanan darah berbagai model tikus hipertensi, dan pasien hipertensi stage 1 (Perez-Viscaino, dkk., 2009). Prinsip kerja lain dari senyawa flavonoid sebagai antihipertensi adalah melalui kemampuanya

JIFFK Vol. 15, No. 1, JUNI 2018, Hal. 29 - 36 
dalam menghambat aktivitas angiotensin converting enzyme. Beberapa senyawa flavonoid seperti luteolin, quercetin, rutin, kaempferol, rhoifolin and apigenin, secara in vitro telah menunjukkan kemampuannya dalam menghambat aktivitas enzim ACE (Guerrero, dkk., 2012)

\section{KESIMPULAN}

EEK-RBJ $(125,250$ dan 500) $\mathrm{mg} / \mathrm{Kg} \mathrm{BB} /$ hari selama 14 hari mampu menurunkan tekanan darah sistol dan diastol tikus hipertensi dengan pola tergantung dosis. EEK-RBJ $500 \mathrm{mg} / \mathrm{Kg}$ $\mathrm{BB} /$ hari selama 14 hari dapat menurunkan tekanan darah sistol dan diastol tikus hipertensi yang diinduksi MSG berturut-turut sebesar 20,04 mmHg dan 13,16 mmHg.

\section{DAFTAR PUSTAKA}

Bachker, C.A., and Brink, R.B.C.V.D., 1963, Flora of java, Volume II (III), NV.Noordhoff, Groningen, The Netherlands

Bhaigyabati, T., Ramya, J., and Usha, K., 2012, Effect of methanolic extract of sweet corn silk on experimentally induced hyperthyroidsm in Swiss albino rats. IRJP, 3(3), 241-245

Depkes RI., 1985, Cara pembuatan simplisia, Departemen Kesehatan Republik Indonesia, Jakarta, 37

Diennazola, Renda, 2012, Manfaat si hitam langka, Tabloid Agribisnis Dwi Mingguan, http://www.agrinaonline.com/show article.php?rid=12\&aid=3530, diakses tanggal 11 Januari 2017

Djaeni, M., Agusniar, A., dan Setyani, D., 2014, Pengeringan jagung dengan metode mixedadsorption drying menggunakan zeolite pada unggun terfluidasi, Prosiding Seminar Nasional Sains dan Teknologi, Universitas Wahid Hasyim, Semarang, 49

Garnida, Y., 2018, Pengaruh suhu pengeringan dan jenis jagung terhadap karakteristik teh herbal rambut jagung (Corn Silk Tea), Pasundan Food and Technology Journal, 5(1), 63-71

George, G.O. and Idu, F.K., 2015, Corn silk aqueous extracts and intraocular pressure of systemic and non-systemic hypertensive subjects, Clin Exp Optom., 98(2),138-149

Guerrero, L., Castillo, J., Quiñones, M.,Garcia-Vallvé, S., Arola, L., Pujadas, G., and Muguerza, B., 2012, Inhibition of angiotensin-converting enzyme activity by flavonoids: structureactivity relationship studies, PLoS One., 7(11), e49493

Guo, J., T. Liu, Han, L., and Liu, Y., 2009, The effect of corn silk on glycaemic metabolism, Journal Nutrition \& Metabolism Biomed Central, 6, 47

Handa, S.S., Khanuja, S.P.S., Rakes, D.D., Longo, G., and Rakesh, D., D., 2008, Extraction technologies for medicinal and aromatic plants, International Center for Sciences and High Technology, Italy, 21-25

Herman, H. dan Bayu P., 2015, Uji antihipertensi infus kombinasi biji dan rambut jagung (Zea mays L.) pada tikus jantan (Rattus norvegicus) dengan metode tail cuff non invasive, Jurnal Media Farmasi, Universitas Hasanudin, Makassar, 12, 93-103

Hidayati, D. N., Anas, Y., dan Nurikha, S., 2015, Peningkatan efek antihipertensi kaptopril oleh ekstrak etanol daun belimbing wuluh (Averrhoa bilimbi L.) pada tikus hipertensi yang diinduksi monosodium glutamat, Jurnal Ilmu Farmasi dan Farmasi Klinik, 12(2), 33-40

Kadir N., 2009, Uji efek diuretik tongkol jagung (Zea mays L.) terhadap kelinci jantan (Oryctolagus cuniculus), Skripsi, Fakutas Farmasi Universitas Hasanudin, Makassar, 4-10

Larson, A. J., Symons, J. D. and Jalili, T., 2010, Quercetin: a treatment for hypertension, a review of efficacy and mechanisms, Pharmaceuticals, 3(1), 237-250

Nessa, Arifin, H., dan Muchtar, H., 2013, Efek diuretik dan daya larut batu ginjal dari ekstrak etanol rambut jagung (Zea mays L.), Prosiding Seminar Nasional Perkembangan Terkini Sains Farmasi dan Klinik III 2013, Fakultas Farmasi Universitas Andalas, Padang, 345-358

Perez-Vizcaino, F., Duarte, J., Jimenez, R., Santos-Buelga, C. and Osuna A., 2009, Antihypertensive effects of the flavonoid quercetin, Pharmacol Rep., 61(1), 67-75 
Yosmar, R., Arifin, H., Mustika, R., 2014, Pengaruh ekstrak etanol rambut jagung (Zea mays L.) terhadap kadar kolesterol mencit putih jantan hiperkolesterol, Prosiding Seminar Nasional dan Workshop "Perkembangan Terkini SAINS Farmasi Klinik IV", Universitas Andalas, Padang, 96-104

Yuniarti, T., 2008, Ensiklopedia tanaman obat tradisional, MedPress, Yogyakarta, 134

Žilić, S., Serpen, A., Akıllığlu, G., Gökmen, V. and Vančetović, J. 2012. Phenolic compounds, carotenoids, anthocyanins, and antioxidant capacity of colored maize (Zea mays L.) kernels. Agricultural and Food Chemistry 60, 1224-1231 